\title{
PAULINE EXEGESIS IN PATRISTIC COMMENTARIES OF OLD TESTAMENT PROPHETS: THE EXAMPLE OF JULIAN OF AECLANUM'S TRACTATUS IN AMOS
}

\author{
Josef Lössl, Cardiff University (LosslJ@ @cf.ac.uk)
}

\begin{abstract}
The surge in Pauline exegesis in the Latin world during the late fourth / early fifth century has been referred to as a "Pauline Renaissance". It produced numerous Pauline commentaries and led to a presence of Pauline motifs in many areas of late Roman cultural and intellectual life. This article is an attempt to show how it influenced not only New Testament but also Old Testament exegesis. Julian of Aeclanum's Tractatus in Amos draws direct links between the figures of Amos and Paul and thus offers a re-interpretation not only of the role of Old Testament prophecy in late antique Christianity but, almost more importantly, of the role of Paul and his "call", or, as it is more frequently understood, his "conversion", from Jewish zealot to Christian apostle. What is suggested here, among other things, is that the link between Amos and Paul in the Tractatus in Amos leads to a greater appreciation of the role of Jewish prophecy and teaching in early Christian thought and of Paul's Jewish identity.
\end{abstract}

\section{Introduction}

Gennadius refers to Julian of Aeclanum as a Biblical scholar (in divinis scripturis doctus) $^{1}$ with a sharp mind (vir acer ingenio). Julian's intellectual encounter with Augustine in the aftermath of the condemnation of Pelagius and Caelestius in May 418 ignited this explosive concoction. Over large parts the debate between the two bishops was about the exegesis of certain passages of the Pauline corpus. ${ }^{2}$ As in divinis scripturis doctus Julian would have taken his exegesis of the Apostle very seriously. ${ }^{3}$ In particular, he would have thought of it not so much as his exegesis

\footnotetext{
${ }^{1}$ Gennadius, De viris illustribus 46 (78 Richardson); J. Lössl, Julian von Aeclanum (Leiden, 2001), pp. 11.42.47.250.273; M. Lamberigts, "Iulianus IV (Iulianus von Aeclanum)," Reallexikon für Antike und Christentum 19 (2000), pp. 483-505. Bede, too, calls Julian an exegete; comm. in Cant. 1 (CCL 119B, 167.170.285).

2 Compare J. Lössl, "Augustine, 'Pelagianism', Julian of Aeclanum and Modern Scholarship," Journal of Ancient Christianity 11 (2007), pp. 129-50 at 129-33.

${ }^{3}$ Note the fervour with which he attacks Augustine for "usurping the Apostle's witness" c. Iul. imp. 1.24 (CSEL 85/1, 21.12): ...inefficaci intentione usurpasti apostoli testimonium.
} 
but as part of a tradition. There had been a surge in Pauline exegesis, Latin and Greek, a generation before Julian. ${ }^{4}$ It revived in part an older tradition, in part it transformed it. Julian of Aeclanum knew about this development. Ironically one of its representatives who influenced him most was Augustine. ${ }^{5}$

Augustine himself had little time for tradition. In this respect he was, as James O'Donnell writes, one of "the last of his kind. No one after him could have the same insouciance toward intellectual and theological predecessors". ${ }^{6}$ It was Julian who introduced the Patristic argument to the controversy with Augustine, though Augustine proved a quick learner, when he responded not only with a barrage of Scripture references, but added yet more Patristic authorities (almost exclusively bishops). He may have compiled this collection with a view to having to justify his position not just to Julian but to the whole church, during his lifetime or after, perhaps at a Council. ${ }^{7}$

Julian has been labelled a rationalist. ${ }^{8}$ But it is him, not Augustine, who is at pains to support his arguments from tradition. ${ }^{9}$ It is difficult to do justice to this

\footnotetext{
${ }^{4}$ To list but the most important ones (some of them dealing only with part of the Pauline corpus), Ambrosiaster (ed. H. J. Vogels, 3 vols., CSEL 81, Vienna 1966-69); Augustine (ed. J. Divjak, CSEL 84, Vienna, 1971: Galatians and Romans); the Budapest Anonymus (ed. H. J. Frede, 2 vols., Freiburg i. Br., 1973-1974); John Chrysostom (PG 61); Jerome (PL 26; R. Heine, The Commentaries of Origen and Jerome on Ephesians (Oxford, 2002); G. Raspanti, CCSL ...); Origen (PG 14; C. P. Hammond Bammel, Der Römerbriefkommentar des Origenes, 3 vols., Freiburg i. Br., 1996; for further editions of fragmentary material of Origen see ibid. and Heine op. cit.); Pelagius (ed. A. Souter, Pelagius' Expositions of Thirteen Epistles of St. Paul, Cambridge, 1931); Marius Victorinus (ed. F. Gori, CSEL 83, Vienna 1986); Theodore of Mopsuestia (ed. K. Staab, Pauluskommentare aus der griechischen Kirche, Münster, 1933; H. B. Swete, Theodori Episcopi Mopsuesteni in Epistolas B. Pauli Commentarii, 2 vols. Cambridge 1880-82).

${ }^{5}$ For an example, note his treatment of Gal 5.16-18, discussed below under Appendix I.

6 J. J. O’Donnell, Augustine. Sinner and Saint (London, 2005), p. 125.

${ }^{7}$ In some sense the occasion did arise, but only after his death, at the council of Ephesus in 431, which he was invited to attend. Had he attended, his controversy with Julian would almost certainly have become an issue. For the role and the impact of the writings against Julian immediately after Augustine's death see M. Vessey, "Opus Imperfectum: Augustine and His Readers, 426-435," Vigiliae Christianae 52 (1998), pp. 264-285; for the development of the Patristic argument during the controversies with Pelagius and Julian see E. Rebillard, "A New Style of Argument in Christian Polemic: Augustine and the Use of Patristic Citations," Journal of Early Christian Studies 8 (2000), pp. 559-78.

${ }^{8}$ Most notably by A. Harnack, Lehrbuch der Dogmengeschichte, vol. 3 (Tübingen, $\left.{ }^{2} 1890\right)$, p. 183, cited by A. Bruckner, Julian von Aeclanum (Leipzig, 1897), p. 176; G. Bouwman, Des Julian von Aeclanum Kommentar (Rome, 1958), p. 23, cited by O. Wermelinger, Rom und Pelagius (Stuttgart, 1975), p. 265; J. Lössl, “Julian of Aeclanum's 'Rationalist' Exegesis," Augustiniana 53 (2003), pp. 79-80.

9 As I argued in Lössl, "Julian of Aeclanum's 'Rationalist' Exegesis," 84-93.102-104, Julian held that arguments from reason, Scripture and tradition had to support each other not to compete with each other. He accused Augustine of first introducing some new doctrinal idea by way of rational argument (namely the idea of "natural sin") and then trying to underpin it by arguments from Scripture and tradition. He held against this his own arguments from reason, Scripture and tradition.
}

\footnotetext{
Josef Lössl, "Pauline Exegesis in Patristic Commentaries of Old Testament Prophets: The Example of Julian of Aeclanum's Tractatus in Amos," in: Journal for Late Antique Religion and Culture 4 (2010) 1-27; ISSN: 1754-517X; Website: http://www.cardiff.ac.uk/clarc/jlarc
} 
trait in the polemical works, where it is easily dismissed as a polemical technique. A comparison of Julian's Pauline exegesis in fragments of his polemical works with that in his non-polemical, exegetical, works, if this is at all possible, may show that this is not so, but that Julian really and rightly does see himself in a wider tradition of Patristic exegesis, a tradition which Augustine seems not to have known (or not to have cared for) to the same extent as Julian. Among the extant fragments from Julian's polemical writings those from Ad Turbantium (Turb.) offer themselves especially for such an investigation. They are not yet as singlemindedly polemical as those from Ad Florum (Flor.) and they may therefore be assumed to contain a wider variety of exegetical techniques, some of which are not exclusively polemical but can also be seen in non-polemical exegetical works. Among the exegetical works the Commentaries on Hosea, Joel and Amos (tr. proph. or Tractatus) stand out, and among them especially the Commentary on Amos (tr. Amos). ${ }^{10}$ We assume that Julian is indeed the author of the Tractatus. ${ }^{11}$ But even if this should one day be convincingly disproved, one can still argue that a comparison like the one proposed here may demonstrate that Julian's exegetical technique even and especially in his polemical works fitted well in the context of fourth and fifth century Pauline exegesis. Vice versa, on the assumption that the Tractatus really is Julian's work, the similarity between the exegetical techniques applied in it with those on display in the polemical works, especially Turb., can be regarded as further evidence for Julian's authorship of the Tractatus.

\section{Paul in tr. Amos and in other Patristic Commentaries of Amos}

The strong presence of Paul in Julian's tr. Amos is striking. It is not so much the quantity of Pauline references as their exegetical treatment which dominates the commentary. In mere quantitative terms it does not even amount to all that much: sixteen citations, paraphrases and "strong" allusions ${ }^{12}$ in total, four from Romans, six from 1 Corinthians, and one each from 2 Corinthians, Ephesians, Galatians, Philippians and 2 Timothy. ${ }^{13}$ Only Theodore of Mopsuestia has fewer Pauline references. Only once in his commentary, in the preface, he explicitely refers to Romans $4 .{ }^{14}$ Otherwise Paul plays no role in his commentary, though it may be

\footnotetext{
${ }^{10}$ For both texts I use the critical edition by L. De Coninck \& E. M. D'Hont (CCL 88, 260-396).

${ }^{11}$ For a Resumée listing and discussing the arguments in favour of this opinion see J. Lössl, “Julian of Aeclanum's Tractatus in Osee, Ioel et Amos," Augustiniana 51 (2001), pp. 11-37.

${ }^{12}$ By "strong" I mean allusions which carry meaning for the exegesis of the passage concerned.

${ }^{13}$ For a detailed breakdown of the passages and their locations see the table under Appendix II.

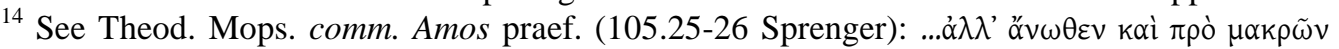

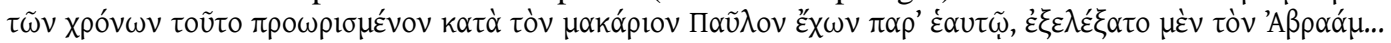
In this respect, being situated in the preface and somehow guiding the exegesis of the whole prophet book, the reference does however fulfil a somewhat similar function as Eph 2:20 does in Julian's tr. Amos. But in contrast to Julian Theodore does not continue with the Pauline motif, but focuses purely on the prophet in his own context. For a modern translation of Theodore's commentary of

Josef Lössl, "Pauline Exegesis in Patristic Commentaries of Old Testament Prophets: The Example of Julian of Aeclanum's Tractatus in Amos," in: Journal for Late Antique Religion and Culture 4 (2010) 1-27; ISSN: 1754-517X; Website: http://www.cardiff.ac.uk/clarc/jlarc
} 
argued that the reference is situated in a key section of his commentary and that in that respect his use of Paul is similar to that in $t r$. Amos. ${ }^{15}$ Jerome's commentary of Amos contains more Pauline references, ca. 40 in all. ${ }^{16}$ Cyril of Alexandria's commentary contains roughly the same number as Jerome's. ${ }^{17}$ But both these commentaries are much longer than tr. Amos (ca. two times and two and a half times as long as tr. Amos) ${ }^{18}$ and both contain far more references than tr. Amos to biblical and non-biblical sources other than the Pauline epistles. ${ }^{19}$ Furthermore, importantly, both Cyril and Jerome use Pauline references very often in clusters with other references, ${ }^{20}$ something that $t r$. Amos rarely does. Consequently, their

Amos see R. C. Hill, Theodore of Mopsuestia: Commentary on the Twelve Prophets (Washington, D.C., 2004).

${ }^{15}$ As a consequence, as H. N. Sprenger, Theodori Mopsuesteni Commentarius in XII Prophetas (Wiesbaden, 1977), pp. 112-13, points out, far less can be said about Theodore's theology on the basis of his commentary on the Twelve Prophets than of his Pauline work (the commentary edited by Swete and the fragments collected by Staab; see above note 5). For Julian of Aeclanum things are slightly different, not least because of the presence of Paul in tr. Amos.

${ }^{16}$ For an overview of Jerome's use of Paul in his comm. in Amos see Appendix III and below n. 21.

${ }^{17}$ Generally, Pauline references are quite frequent in Cyril's commentary. Yet there are big and significant gaps. The whole first book has only one Pauline reference at the end, and the elaborate exegesis of Am 6:1 has none at all. This is significant if compared with tr. Amos, where the whole exegesis is developed against the background of Rom 1:18-32. Pauline references in Cyril are also outweighed by other NT references, from James, 1 John, Acts and Gospels, but especially by OT references, especially Isaiah, Jeremiah and Hezekiel, 1 and 2 Kings, Psalms, Proverbs and Job. Paul is rarely cited in his own right but often integrated into clusters. Noteworthy among the frequent "Pauline" references in Cyril's commentary are those to Eph. Eph 2:6, 4:7, 4:14, 5:5, 5:9 and 6:12 are repeatedly cited. Perhaps this reflects the role of the epistle in fourth and fifth century theology, especially in Alexandria (see Heine, Commentaries, pp. 48-71). A detailed list of Pauline references can be found below under Appendix IV.

${ }^{18} \mathrm{Tr}$. Amos takes up 69 pages in the CCL edition, Jerome's comm. in Amos takes up 137 pages and Cyril's commentary extends over 87 columns in Migne's PG (counting one column per page). CCL has ca. 250 words per page, PG ca. 500 words per column (Greek). This amounts to ca. 17,500 words for tr. Amos, 34,250 words for Jerome's comm. in Amos and 43,750 words for Cyril's comm. in Amos. Cyril's commentary has no Pauline references at all for Amos 1 and Pauline references become more frequent towards end of the commentary.

${ }^{19}$ A rough estimate suggests that Jerome's commentary contains ca. 350 OT references and ca. 100 NT references from parts of the NT that are not Pauline. Cyril's has a similar proportion of OT and NT references. Classical and Patristic references (or sources) have not been counted in this survey, as they do not fulfil the same function as biblical references in the attempt to establish an authoritative reading of a text. Thus for every Pauline reference in Cyril and Jerome there are more than ten others and often the Pauline references are closely embedded in groups or clusters of them with the result that a specific Pauline interpretation of a passage is often lost, even when Pauline texts are cited in connection with it. Tr. Amos in contrast has ca. 50 OT references and 15 NT references other than Pauline. Especially the NT proportion is striking. Already in quantitative terms alone, therefore, Pauline material dominates $t r$. Amos, and when it occurs within a cluster it often tends to dominate it too.

${ }^{20}$ The following examples from Jerome's commentary might give an impression: Hier. comm. in Amos 1.3.2-3 (CCL 76, 244.31-33) combines Gal 4:9 and 1 Cor 14:38 with Lk 13:27. Because

Josef Lössl, "Pauline Exegesis in Patristic Commentaries of Old Testament Prophets: The Example of Julian of Aeclanum's Tractatus in Amos," in: Journal for Late Antique Religion and Culture 4 (2010) 1-27; ISSN: 1754-517X; Website: http://www.cardiff.ac.uk/clarc/jlarc 
exegesis never takes on a characteristically Pauline line. But now that is precisely what happens in tr. Amos, where a Pauline reference is often the dominant one in a passage (apart from the lemma) and provides the key or corner stone for quite a number of interpretations of important passages.

What is most striking is that there are hardly any overlaps between Julian's and Jerome's citations. ${ }^{21}$ It is well known that tr. Amos depends heavily on Jerome's comm. in Amos. Some have even suggested that Julian simply copied Jerome. ${ }^{22}$ The evidence gathered in this paper should drive another nail into the coffin of this theory. In fact Julian's emphasis is quite different from Jerome's, on whose text tr. Amos none the less depends in many ways, but not in this. To introduce Paul as a prophet and to treat the prophet like an apostle by putting key Pauline passages alongside passages from Amos and comparing them by giving them an elaborate exegetical treatment is a technique which Julian has not from Jerome or

of the Gospel passage the Pauline character of the exegesis is relativised. 1.3 .8 (246.91-94; 247.127) groups Rom 10:20 and 1 Cor 6:17 with Is 65:1 and Rom 16:20 with Ps 139:6. Especially revealing here is first the phrase: Paulus loquitur, and immediately following: et rursum in Dauid legimus. Similarly in 2.4.9 (265.319) 1 Cor 7:9 is combined with 1 Peter 4:12 and Jerome makes a point of letting apostolus be joined, and dominated, by princeps apostolorum. In 2.4.10 (267.369-372) we have first an allusion to Gal 2:19-21 and then in rapid succession citations of Rom 6:8, 2 Cor 4:10, Gal 2:20 and Rom 13:12. But this ostensibly Pauline cluster is interwoven with Is 9:8, Gen 32:2425 and Ps 37:6. Whenever a Pauline citation is introduced, it is immediately connected with an OT reference, which then has the last word. But even when the Pauline material is overwhelming, this impression is never completely overcome. Ironically, it is precisely the sheer number of references without any further exegetical development that frustrates the creation of a Pauline focus. This is most obvious in 1.2.13-16 (242.434-461) where in rapid succession the following verses are cited: 1 Cor 9:24, Gal 5:7, Phil 3:12, 2 Tim 4:7-8, Rom 9:16, and 1 Cor 1:19. The list ends with an allusion to Eph 6:11.13.17 and it is interspersed with Ps 138:7, Is 29:14 and Ps 143:1-2. Enough Pauline material to create a Pauline focus one should think. But it does not happen. The citations remain citations. There is no exegetical development that would breath some life into them. A similar case in Cyril's commentary is the explanation of Amos 8:10 (PG 71, 556), where in rapid succession Lk 16:14, Mt 27:45, Rom 11:25, 2 Cor 3:15, Ps 78:24, Lk 13:27-28, Mt 27:51 and Is 50:3 are cited. Here, too, as in Jerome, the exegete's interest is far wider than to develop a Pauline interpretation of Amos. This also squares with M. Simonetti's observation that in general Cyril prefers literal interpretation and keeping the OT to itself: "Note sul commento di Cirillo d'Alessandria ai Profeti minori," Vetera Christianorum 14 (1977), pp. 301-30 at 328-29.

${ }^{21}$ There may be dependencies. For instance in the preface to Book 2 of his commentary (255.34) Jerome cites 2 Cor 12:9-10 (...uirtus in infirmitate perficitur...) and further on (255.4-5, 30-31) Gal 5:17 (caro concupiscit aduersus spiritum...) and Rom 7:15.24 (non quod uolo...). Jerome's exegesis of the second cluster squares with the findings discussed under note 5. Gal 5:17 is read together with Mt 26:41 and interpreted from an ascetic point of view. Rom 7:15.24 is accompanied by a comment stating that the flesh is weak. The concern here is not to express a genuine Pauline anthropology, but to make use of Paul for a commentary of Amos. 2 Cor 12:9-10, however, is different. Here the similarities of Amos and Paul must come to mind (especially the aspect of the prophet's and the apostle's 'weakness' and vulnerability); and although (yet again) Jerome does not develop the motif, it is developed in tr. Amos 1.1.1 (CCL 88, 261).

${ }^{22}$ Notably Bouwman, Des Julian von Aeclanum Kommentar, pp. 125.131; for a critique of this view see the notes in Lössl, "Julian of Aeclanum's Tractatus," pp. 36-37.

Josef Lössl, "Pauline Exegesis in Patristic Commentaries of Old Testament Prophets: The Example of Julian of Aeclanum's Tractatus in Amos," in: Journal for Late Antique Religion and Culture 4 (2010) 1-27; ISSN: 1754-517X; Website: http://www.cardiff.ac.uk/clarc/jlarc 
(as far as one can see) any other exegete of his time. One might speculate that the relevant passages are traces of a lost commentary (perhaps by Origen?). For lack of any evidence however we have to assume that Julian developed the concept himself and carried it out, with the best exegetical knowledge and skill available to him in his day and age.

\section{Paul in tr. Amos and the Early Christian Understanding of Prophecy}

Paul takes over right from the beginning of tr. Amos. His persona comes to stand beside Amos, while his thought assumes priority. The very concept of prophecy with which Julian interprets Amos is influenced by Paul's concept of prophecy as developed in 1 Corinthians. ${ }^{23}$ This also says something about Julian's view of Paul. Early Christian exegetes were often at pains to draw a clearer line between Old and New Testament understandings of prophecy than this. In Julian we find a more synthetic view.

The prophets, Julian sets out in the preface to his commentary, safeguard not only the magisterium of the Synagogue, but also the foundation of the church. To this the teacher of the gentiles, Paul, bears witness. For he commends the building of the Church upon the teaching of the apostles and the prophets. ${ }^{24}$ Julian alludes here to Eph 2:20a: The church is built on the teachings of the apostles and prophets. Both strands of teaching taken together make up its foundations. But the wording of the passage (aedificari ecclesiam) also evokes 1 Cor 14:4, where "building up the church" is identified with "prophesying".

Now the concept of prophecy in the Early Church generally was a complex and problematic one. ${ }^{25}$ Early Christian writers sought to define it against Old Testament concepts as well as against pagan and gnostic concepts. At the heart of the problem lay the tension between chaos and order, irrationalism and rationalism, enthusiasm ("ecstasy") and reason, authority and criticism, poetry and poetics ("exegesis"). ${ }^{26}$

\footnotetext{
${ }^{23}$ For some of what follows see now also J. Lössl, "Julian of Aeclanum's Prophetic Exegesis," Studia Patristica 43 (2006), pp. 409-21, and id. "Poets, Prophets, Critics and Exegetes in Classical and Biblical Antiquity and in Early Christianity," Journal of Late Antique Religion and Culture 1 (2007), pp. 1-16.

${ }^{24}$ See Iul. Aecl. tr. Amos praef. (CCL 88, 260.6-10) [...prophetae...] qui non solum magisterium Synagogae, sed etiam fundamentum Ecclesiae praestiterunt, teste magistro gentium, qui aedificari Ecclesiam super doctrinam apostolorum prophetarumque commendat.

${ }^{25}$ For the development of the concept of prophecy in Early Christianity in its Hellenistic context see D. Aune, Prophecy in Early Christianity (Grand Rapids, MI, 1983); C. Forbes, Prophecy and Inspired Speech in Early Christianity (Tübingen, 1995).

${ }^{26}$ For a discussion of the first four junctures see L. Nasrallah, An Ecstasy of Folly. Prophecy and Authority in Early Christianity (Cambridge, MA, 2003); on the fourth juncture, A. Ford, The Origins of Criticism (Princeton, 2002); for the fifth N. Kershaw Chadwick, Poetry and Prophecy (Cambridge, 1952); J. L. Kugel (ed.), Poetry and Prophecy. The Beginnings of a Literary Tradition (Ithaca-London, 1990). In a certain sense A. Stewart-Sykes, From Prophecy to Preaching. A Search
} 
In Julian's time many issues which had been controversial in earlier centuries had been settled and become integrated in the vocabulary and rhetoric of theological discourse. Thus right at the beginning of the preface to the Tractatus, Julian calls David, whom he assumes to be the poet-composer of the Psalms, a divinely inspired poet and bard, fidicen, a word very similar to uates, which had been used in pagan Roman religion for poets like Virgil and Horace. In the same breath Julian equates David to the prophets whom he is about to comment upon. ${ }^{27}$ Now, in the preface to tr. Amos, he more or less equates Paul to Amos and thus blurs the boundaries between Old and New Testament concepts of prophecy.

This kind of exegesis of an Old Testament prophet book had only become possible after a long development, though in some sense this development, which had begun with Philo and Paul, was now also coming full circle. In earlier generations the discourse had been dominated by the exclusivist heresiological and polemical rhetoric of the Montanist controversy. It is significant that in this controversy both sides could, and did, credibly appeal to Paul. ${ }^{28}$ This was possible because there are tensions already in Paul between ecstatic and non-ecstatic ("rational") prophecy, and between prophecy and exegesis. These tensions did not originate with Paul. They can also be traced in other writers, for example in Philo, ${ }^{29}$ who may have influenced Paul, at least indirectly in the sense that both men shared a common intellectual background. ${ }^{30}$ And there is a yet deeper dimension to this. Ecstasy, whether as trance or as heightened intellectual awareness, is a state of mind not limited to any particular religious or cultural tradition, or to any particular method of acquisition. It can occur spontaneously, or it can be generated with the help of psychological techniques. ${ }^{31}$ Most notably however it can also be learned in a more enlightened educational context through the acquisition of certain poetic, rhetorical (exegetical) and intellectual skills including the ability to learn by heart, recite and explain poems, epics, hymns, psalms and other literary forms. Early Greek epic and its exegesis are thought to have developed in this way. ${ }^{32}$ This development

for the Origins of the Christian Homily (Leiden, 2001), belongs here, as does E. E. Ellis, Prophecy and Hermeneutic in Early Christianity (Tübingen, 1978).

${ }^{27}$ Tr. proph. praef. (CCL 88, 115); Lössl, "Julian of Aeclanum's Prophetic Exegesis,” p. 409-11.

${ }^{28}$ See for this e. g. Nasrallah, An Ecstasy of Folly, pp. 178 and 185-193 (on Tertullian and the anti-Phrygian source which Nasrallah assumes is embedded in Epiphanius' Panarion).

${ }^{29}$ See for this J. R. Levison, "Two Types of Ecstatic Prophecy According to Philo," The Studia Philonica Annual 6 (1994), pp. 83-89. Levison argues that Philo used "ecstasis" not only to denote a state of trance but also a state of heightened intellectual awareness. In the wake of this ambiguity Paul's use of "prophecy" and "ecstasy" is open to interpretation as well; see e. g. T. Callan, "Prophecy and Ecstasy in Greco-Roman Religion and in 1 Corinthians," Novum Testamentum 27 (1985), pp. $125-40$ at $133-36$.

${ }^{30}$ See M. N. A. Bockmuehl, Revelation and Mystery in Ancient Judaism and Pauline Christianity (Tübingen, 1989).

${ }^{31}$ See the observations made by Kershaw Chadwick, Poetry and Prophecy (above n. 27).

${ }^{32}$ See for this Ford, Origins of Criticism.

Josef Lössl, "Pauline Exegesis in Patristic Commentaries of Old Testament Prophets: The Example of Julian of Aeclanum's Tractatus in Amos," in: Journal for Late Antique Religion and Culture 4 (2010) 1-27; ISSN: 1754-517X; Website: http://www.cardiff.ac.uk/clarc/jlarc 
culminated during the Hellenistic period, when it converged with a number of traditions other than Greek.

During that period one way of tackling the tension between ecstasy and reason was to synthesise and define one as the other. The tendency to do this has, as we saw, been observed in Philo and Paul. Sometimes controversies broke out. Some Early Christian authors in their quest to define their identity sought to draw a clear line between their own different concepts of prophecy (Old and New Testament, ecstatic and non-ecstatic) on the one hand, and non-Christian, pagan, concepts on the other. These distinctions could sometimes be arbitrary and inconsistent. John

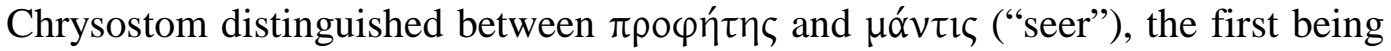
conscious of what he is saying, and capable of judging it, the second being ecstatic and therefore not in control. ${ }^{33}$ But the classical use does not warrant such a clear distinction between the two expressions, and Paul himself, or so it seems, did not suppress ecstatic prophecy, nor did early, pre-Montanist, Christian writers. The "Montanists" for their part had a strong case when they justified their practices against their opponents, and they did so on rational grounds, foremost among them Tertullian. ${ }^{34}$ Authors writing in the post-Montanist period were aware of that. Origen did not so much simply refute ecstatic prophecy ${ }^{35}$ as to try and redefine it within a rational framework: ${ }^{36} \mathrm{~A}$ man, he writes, who has the spirit of prophecy, cannot be forced against his will to speak (non inuitus loqui cogitur), as men who are possessed by unclean spirits. Rather, he speaks whenever he wants and when reason requires it: cum uult et ratio postulat.

Jerome, under Origen's influence, if not outright dependence, ${ }^{37}$ writes similarly in his commentary on Ephesians: ${ }^{38}$ "It must then either be accepted along with

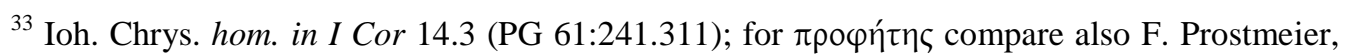
Der Barnabasbrief (Göttingen 1999), pp. 255-83, who writes that although it was clear that the

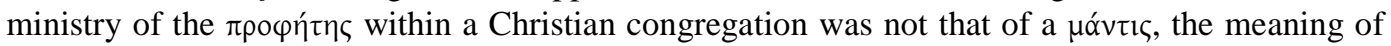
the word in ordinary language was open to such an interpretation. This seems also to be suggested by Ammianus Marcellinus 15.7, who reports that Athanasius had the reputation of being gifted as

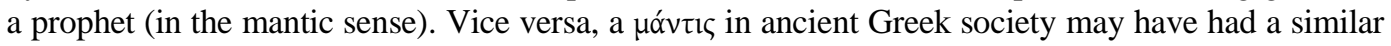
role as a זрофи́ пn in an early Christian community; cf. R. C. T. Parker, 'Prophētēs,' The Oxford Classical Dictionary, $3^{\text {rd }}$ ed. 1996, p. 1259.

${ }^{34}$ See for this famously Tert. anim. 9.4 (Waszink), where Tertullian relates ecstatic prophecy and its subsequent explanation as a rational process; discussed in J. Lössl, "Prophetie und Homilie," in F. Prostmeier, K. Wenzel, eds., Zukunft der Kirche - Kirche der Zukunft (Regensburg 2003), pp. 61-74, 68.

${ }^{35}$ Against C. P. Bammel, "Die Prophetie in der patristischen Exegese zum ersten Korintherbrief," in Id., Tradition and Exegesis in Early Christian Writers (Aldershot, 1995), XIV, p. 160. Though Bammel is clear and straightforward in her account and her argument is based on textual evidence, she does not ask how Origen could have sustained it in the wider context of his work. A passage that may appear to be clear and straightforward while taken on its own might appear less so when put in a wider context.

${ }^{36}$ Origen. (tr. Rufin.) comm. in Rom 7.5 in Rom 8:23-25 (II 107 Lommatzsch).

${ }^{37}$ R. E. Heine, “Recovering Origen's Commentary on Ephesians from Jerome," The Journal of Theological Studies 51 (2000), pp. 478-514.

Josef Lössl, "Pauline Exegesis in Patristic Commentaries of Old Testament Prophets: The Example of Julian of Aeclanum's Tractatus in Amos," in: Journal for Late Antique Religion and Culture 4 (2010) 1-27; ISSN: 1754-517X; Website: http://www.cardiff.ac.uk/clarc/jlarc 
Montanus that the patriarchs and prophets spoke in ecstasy and did not know what they said, or, if this is blasphemous inasmuch as the spirit of prophets is subject to prophets (1 Cor 14:32), they understood very well what they spoke."39 Montanus and Montanism were no longer live issues in Jerome's time. The question how to relate prophecy and ecstasy however was. And where Jerome does not provide an answer, Julian does, as did Diodore of Tarsus before him, who, similar to Origen, compared the raptus of the prophet with the ratio of the exegete and saw both united in one person. ${ }^{40}$

The quest for a rational concept of prophecy must not be mistaken for a quest to abolish prophecy. The point was precisely not to abolish the original tension between prophecy and reason, but to define the conditions under which it was to be maintained. One further aspect here is the relationship between the spoken and the written word and between canonical and non-canonical scripture. As the canon was formed and interpreted in an increasingly literary and eclesiastically regulated context, the tension became ever more subtle. On the one hand, prophecy could now be called doctrine and the prophet a teacher, as in the Budapest Anonymus, who comments upon 1 Cor 14:3: Notandum quoniam "prophetiam" doctrinam dicit: ${ }^{41}$ "Note, "prophecy' here means doctrine." On the other hand, doctrine still had to be interpreted, i. e. "prophecy" was still required. Thus a generation before Julian Ambrosiaster wrote about prophecy that it was either prediction of future events, in particular the coming of Christ, or it was interpretation, exegesis, of biblical texts relating to these events. There is no fundamental distinction here between Old Testament prophecy and later forms of prophecy. Both aspects are included in 1 Cor 14:3-4. ${ }^{42}$ If Julian is expressing a similar view by relating, or even equating, Paul and Amos in the preface to tr. Amos, he does in some sense link up with Philo and Paul. ${ }^{43}$ And as the example of Ambrosiaster indicates, he does so inspired by the study of Paul. The preface of tr. Amos thus announces

\footnotetext{
${ }^{38}$ Hier. comm. in Eph 3:5 (PL 26:479BC); Hier. ep. 41.4 (CSEL 54:314).

39 The translation is taken from R. E. Heine, The Commentaries of Origen and Jerome on St. Paul's Epistle to the Ephesians (Oxford, 2002), p. 145.

${ }^{40}$ See Diod. in Rom 12:6-8 (106.9 Staab); Lössl, Julian von Aeclanum, p. 180.

${ }^{41}$ Budapest Anonymus 1 (155.064 Frede).

${ }^{42}$ Ambrstr. comm. in 1 Cor 14:3-4 (CSEL 81, 150): "qui loquitur lingua se ipsum aedificat, qui uero profetat ecclesiam aedificat [1 Cor 14:3]". Per id, quod enim solus forte scit quod loquitur, se solum aedificat; nam qui profetat omnem plebem aedificat, dum intellegitur ab omnibus quid loquatur. Profetas interpretes dicit scripturarum. Sicut enim profeta futura dicit quae nesciuntur, ita et hic, dum scripturarum sensum, qui multis occultus est, manifestat, dicitur profetare.

${ }^{43}$ Or to Origen who at one point defines prophecy as semantics: Orig. comm. in 1 Cor 14:3-4

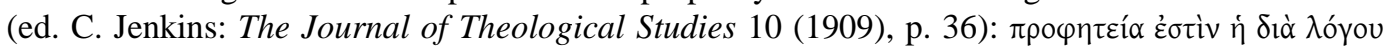

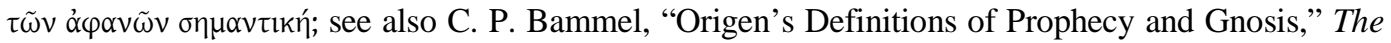
Journal of Theological Studies 40 (1989), p. 490. Again, as above n. 36, Bammel's interpretation of this passage is philologically correct. But the tension between prophecy and gnosis should be seen in a wider context. Gnosis has its semantics, and the semantics of prophecy can also aim at gnosis.
}

Josef Lössl, "Pauline Exegesis in Patristic Commentaries of Old Testament Prophets: The Example of Julian of Aeclanum's Tractatus in Amos," in: Journal for Late Antique Religion and Culture 4 (2010) 1-27; ISSN: 1754-517X; Website: http://www.cardiff.ac.uk/clarc/jlarc 
what will be borne out in other parts of the commentary, namely that its author is a "Paulinist", of a similar kind as Ambrosiaster, Pelagius, or the early Augustine.

\section{A Prophetic Exegesis of Paul and a Pauline Exegesis of the Prophet}

The preface of tr. Amos, as it relates Amos' prophecy to an early fifth century take on Paul's understanding of prophecy as prophecy and its interpretation (influenced by Philo or more generally Hellenistic Jewish concepts), without distinguishing Old and New Testament understandings of prophecy, bears witness to early fifth century Paulinism. This is consistent with Antiochene influences spotted elsewhere in the Tractatus, Diodore's explanation of the raptus of the prophet and exegete mentioned earlier, the concept of theoria ${ }^{44}$ i. e. the historical understanding of a deeper scriptural sense as opposed to the meta-historical understanding of allegory, or the idea that the ecstasy of the Old Testament prophets was historically limited, in the sense that they had only a limited sense of the coming of Christ (or none at all) and that later interpretation may well add something to the meaning which they originally intended in their proclamations. ${ }^{45}$ Thus a post-New Testament exegete may ascribe to Amos's prophecies a larger, though by no means necessarily less appropriate, meaning than that which the prophet may have had in mind when he expressed them. In other words, the prophetic and apostolic message was able to develop. Exegesis could be creative, synthetic, not just analytical. In this sense, interestingly, the Old Testament prophet, whether he was in ecstasy or not, was definitely not in control of his message. His view of the future was limited to the historical context in which and for which he prophesied. The wider context, and this includes the New Testament context, has been attributed to the prophecy by way of what we might today call reception, but reception as a highly active and creative process. This would mean that only in conjunction with its interpretation in the light of its fulfilment could prophecy be called "complete" and fully "true". What matters from this point of view is not whether or not prophecy was ecstatic when it was first proclaimed, but rather, whether it makes sense in the context of the whole of salvation history. This seems to have been the Antiochene view and also the view held by the author of the Tractatus.

A good example for the latter may be Julian's understanding of hyperbole and what he sometimes calls, in an unusual understanding of the word, excessus. ${ }^{46}$ If, for example, according to Julian, the prophet speaks of a realistic historical event, e. g. the destruction of Jerusalem, in apocalyptic terms, he is exaggerating, i. e. he uses hyperbole. But if an early Christian exegete reads that prophecy in view of

\footnotetext{
${ }^{44}$ See Lössl, Julian von Aeclanum, p. 180-83.

${ }^{45}$ See Lössl, Julian von Aeclanum, p. 172 on tr. Amos 2.9.11-12 (CCL 88, 327-328).

${ }^{46}$ Though not in tr. Amos; see tr. Osee 2.9.10 (CCL 88, 189.180); 3.12.1 (207.4-11); tr. Iohel 3.8 (CCL 88, 255.98); and G. Bouwman, "Zum Wortschatz des Julian von Aeclanum," Archivum Latinitatis Medii Aevi 27 (1957), pp. 143-64 at 149.
} 
Christ's second coming, then that which was hyperbole in regard to the original historical context, will turn out to be an understatement in regard to the anticipated eschatological event. When Christ comes, his coming will be an infinitely more momentous event than the sack of Jerusalem was either in the prophet's vision prior to 587BC or in Israel's memory afterwards.

If we take Julian's authorship of the Tractatus seriously, it is this kind of aspect which we must consider. For example, when Augustine - in the context of the Pelagian Controversy - criticises Julian's use of the adverb "hyperbolicos" 47 with reference to Rom 1:28 (tradidit illos deus in reprobum sensum, ut faciant quae non conueniunt), ${ }^{48}$ Julian's use of hyperbole in his exegesis as a whole must be held against it. This particular verse, Rom 1:28, Julian interprets as follows, and here Augustine provides a rare literal quotation from Julian's Ad Turbantium:

"When Paul denounces the crimes of the wicked, he amplifies (aggrauauit) them by using for them names of punishments which they incur, and in so far as his heart, the seat of all virtues, is horrified by their blatant shame, he is saying that such people appear to him not so much as perpetrators than as damned."

The significant expression here is aggrauauit. Speech-acting almost like an Old Testament prophet Paul, according to Julian, uses exaggerating language in order to highlight the real, ultimate, not immediately obvious, meaning of the crimes which he denounces, to get the purpose of his message across; i. e. for rhetorical reasons, and not to indicate that there exists a causal link between the damnation of the damned (e. g. in the sense that they are not elected) and their evil-doing, as Augustine suggested.

\footnotetext{
${ }^{47}$ Unusually, Julian seems to have spelled this in Latin characters. Normally, if an author wanted to revert to the Greek, he would spell it in Greek characters, like Jerome in his commentary on Ezechiel, Hier. comm. in Ez. 31.1 (CCL 75:438.138-140): "Videbam Satanam quasi fulgor de

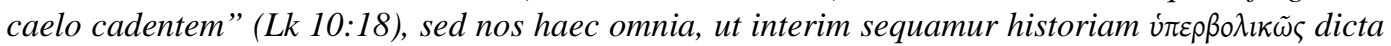

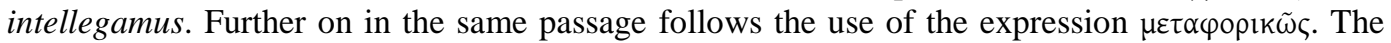
only other passage where I found hyperbolicos in Latin characters was Prosper, comm. in Ps 104:29/30 (PL 51:300C): "Dedit terra eorum ranas in penetralibus regum ipsorum" hyperbolicos dictum est, tamquam ipsam terram eorum conuertisset in ranas. Normally, when Latin characters were used, the Latinised form was also used, hyperbolice, as in Rufin. Orig. comm. in Rom 7:12 (Bammel). The Latin translation of the expression is, of course, exaggeranter or per exaggerationem, or similar, and Julian made use of this phrase as well, e. g. Turb. frg. 321 (CCL 88:395.443-444): Exaggerat ... Apostolus uim consuetudinis; or tr. Amos 1.2.6 (CCL 88:270.77-78): Exaggeratur autem illo sensu delinquentum reatus, quia dedita opera quae erant funesta sectantes, non solum neglegere, sed etiam odisse iustitiam deteguntur.

${ }^{48}$ Aug. c. Iul. 5.10-11 (PL 44:789); Iul. Aecl. Turb. 165 (CCL 88:374.60-65): Cum inueheretur in impiorum crimina, poenarum ea nominibus aggrauauit, quantumque pectori suo, uirtutum omnium domiciolio, turpitudo horreret ostendens, non tam reos quam damnatos sibi tales ait uideri.
}

Josef Lössl, "Pauline Exegesis in Patristic Commentaries of Old Testament Prophets: The Example of Julian of Aeclanum's Tractatus in Amos," in: Journal for Late Antique Religion and Culture 4 (2010) 1-27; ISSN: 1754-517X; Website: http://www.cardiff.ac.uk/clarc/jlarc 
But which verses is Julian here referring to? Augustine cites Rom 1:28 and, a little further down in the same passage from $c$. Iul. 5.10-11, Rom 1:23-24. ${ }^{49}$ If Julian says that Paul is here speaking of vices in terms of the punishments which they incur, he may have been thinking along the lines of Stoic apatheia, i. e. that being prone to desideria is equivalent to being punished. The responsible, free, act which justifies the punishment would at this stage already have been committed. This would have been the decision to be overcome by these desires; though the question arises, whether there ever was a point in time when that decision could have been taken, as bad habit (mala consuetudo) was developing from the time when the wicked person was not yet mature. Julian on the other hand would argue that a free decision for the better could be taken at any time. ${ }^{50}$ This is how Julian thinks, as is obvious from the following fragments, Turb. frg. 166 and 167, where he adds, again literally:

"For they were already inflamed with desire for shameful acts. In what way therefore are they to be believed to have fallen (cecidisse) into doing such things by the power of a God who makes them do such things (per potentiam tradentis dei)? [Rather,] when they are spoken of (dicuntur) as having been handed over or delivered up (traditi) to their desires, they should be understood (intellegendi sunt) as having been left (relicti) by divine patience, not compelled (compulsi) to commit sins through God's power. For,"

Julian adds in fragment 168,

"as the Apostle says (Rom 2:4): 'God's goodness leads you to repent", not, is the implication, to develop desires for evil deeds. ${ }^{51}$

When Julian makes these comments, he clearly thinks not only of the few verses cited by Augustine (on idol worship), which express the basic principle of idolatry, Rom 1:23-24 and 1:28, but he also has in mind those that develop the catalogue of sins in detail and deal more with the consequences of the primeval sin and with its punishment. Rom 1:26 calls these concrete sins passiones ignominiae. Rom 1:27 speaks of people who in desideriis aestuabant or exarserunt, a phrase to which Julian alludes in frg. 166, but refers specifically to sodomy and homosexuality.

\footnotetext{
${ }^{49}$ See n. 49; Rom 1:23-24: immutauerunt gloriam incorruptibilis dei in similitudinem imaginis corruptibilis hominis et uolucrum et quadrupedum et serpentium: propter quod tradidit illos deus in desideria cordis eorum in immunditiam.

${ }^{50}$ See for this the discussion in Lössl, Julian von Aeclanum, pp. 140-46.

${ }^{51}$ Iul. Aecl. Turb. frg. 166-168 (CCL 88:375.74-79): Iam enim flagitiorum desideriis aestuabant. Quomodo ergo per potentiam tradentis dei putandi sunt in talia facta cecidisse? Cum desideriis suis traditi dicuntur, relicti per diuinam patientiam intellegendi sunt, non per potentiam in peccata compulsi. Ait Apostolus: 'Bonitas dei ad paenitentiam te adducit' (Rom 2:4).
} 
Rom 1:29 lists injustice, malice, fornication, avarice, fraud, envy, arrogance, murder, strife, lack of respect for parents and elders, social ills etc. ${ }^{52}$

Now in the light of this let us return once more to tr. Amos. Amos 2:4 and 6 announce God's punishment of Judah and Israel for the three, four crimes which they committed and which are so grave that God will not pardon (conuertere) ${ }^{53}$ either of the two: Super tribus sceleribus Iuda (2:6 Israhel) et super quattuor non conuertam eum. The crimes are, in detail, 1) disregarding God's Law and commandments, 2) engaging in idolatry, 3) committing social injustice, 4) committing sexual perversion (in this case father and son visiting the same prostitute). Judah is blamed with 1), Israel with 2) to 4). Julian interprets the four verses (4-5 and 67) as follows. He first draws attention to the religious aspect focusing on Judah: After accusing all the other nations of their evildoings, he argues, the prophet turns to the religious crime (religionis facinus) of Judah, their abandoning of God's Law, by which they had been singled out and privileged as a nation among all others, in toto orbe. Instead of living up to that status they are now subjecting themselves to idol cults. Consequently, they received the reward they deserved. Judah and Jerusalem were consumed by fire. It was the Babylonians through whom the prophecy was fulfilled (Amos 2:5: et mittam ignem et Iudam, et deuorabit aedes Hierusalem). ${ }^{54}$

Israel in contrast is not accused of idol worship, but of crimes violating mores. Not that these were worse than crimes violating ritual laws, they were however the fruit of religious corruption (fructus foedae religionis), and, Julian adds, Israel behaved worse in committing them than all the other nations (ceteris gentibus nequiores). One led to the other, the denial of God on the ground of superbia led to disregard for neighbour and brother, i. e. to social injustice and oppression of the poor, and then to disregard for the sisters and the brother's daughters, i. e. to sexual exploitation. At this point in the commentary Julian cites Amos 2:7b, which is missing from the lemma. It reads: Viam humilium declinant. This, Julian says, can be understood in two ways: 1) They leave the way of the humble and follow a different path in life; 2) In the courts they ruin the just cause of the poor through fraud (in iudiciis iustam inopum causam fraude commaculant). To this Julian cites Ps 49[Hebr. 50]:18.20: "When you see a thief, you go with him, and you have also common cause with adulterers ... You defame your brother, you callously offend the son of your mother." And it is at this point that Julian adds: "But that kind of understanding 'exaggerates' the guilt of the delinquents, because, pursuing as they were activities dedicated to that which is outright nasty, they were exposed as not merely neglecting, but as actively hating justice." 55 It is possible that Julian had

\footnotetext{
${ }^{52}$ For a table of the presence of Rom 1:18-32 in Turb. and tr. Amos see below Appendix V.

${ }^{53}$ For this meaning of conuertere see A. Souter, A Glossary of Later Latin (Oxford 1949), p. 78.

${ }^{54}$ Tr. Amos 1.2.4-7 (CCL 88:268-270).

${ }^{55}$ Tr. Amos 1.2.6 (CCL 88:270.77-79): exaggeratur autem illos sensu delinquentum reatus, quia dedita opera quae erant funesta sectantes, non solum neglegere, sed etiam odisse iustitiam

Josef Lössl, "Pauline Exegesis in Patristic Commentaries of Old Testament Prophets: The Example of Julian of Aeclanum's Tractatus in Amos," in: Journal for Late Antique Religion and Culture 4 (2010) 1-27; ISSN: 1754-517X; Website: http://www.cardiff.ac.uk/clarc/jlarc
} 
Rom 1:32 in mind when formulating this conclusion, especially since the exegesis of the passage so far is structured strikingly similar to Rom 1:27-29. And it would fit the general picture if Julian also considered Rom 1:32 to be an exaggeratio in the sense that from his point of view Paul could not have seriously argued that the perpetrators had had a full insight into the evil nature of what they were doing; for that would have meant that they had evil wills and evil natures themselves. ${ }^{56}$

Julian also detects here an "order" or a logic of sin and evil:

"The prophet," he writes, "continues with a detailed listing of the various crimes. After injustice and presumption he touches upon sins of pleasure: 'Son and father,' he says, 'join the same girl, and thus violate my sacred name.' He demonstrates in what large numbers of delinquents bad habit (consuetudo) enters. 'First,' he says, 'you deny citizens justice in court and compassion in adversity; then follows, in a continuous development, that not even the laws of nature itself are kept any more in your society. But moving on from shameful conduct generally to incest in particular fathers together with their sons visit the same prostitutes. So people show no more respect, first to other citizens, and eventually not even to their own parents. Surely, through this crime of yours my holy name has been violated as well, and the nations are talking among each other like this: 'What kind of God is that, whose people, said to be his very own, appears to be so horrible?","57

After looking at this passage the references to hyperbole and exaggeration in Turb. may read slightly different from the way Augustine would have liked them to be read. In Julian's view Paul described the way of the Gentiles into sin by way of bad habit in exactly the same "exaggerated" manner as Amos described the way of his people into sin. He applied the prophetic order (ordo propheticus): ${ }^{.8}$ This is what will happen, if this kind of behaviour is drawn to its bitter end. And this may also be how a passage such as Turb. frg. 321 has to be understood: "The Apostle

deteguntur; cf. Rom 1:32: qui cum iustitiam dei cognouissent non intellexerunt quoniam qui talia agunt digni sunt morte...

${ }^{56}$ According to T. D. J. Chappell, Aristotle and Augustine on Freedom (London 1995), Augustine first introduced the latter idea. Chappell does not discuss Julian's controversy with Julian, but it seems obvious that in this question Julian would have sided with Aristotle and maintained that evil deeds are at least partly due to the perpetrators' albeit at least partially culpable lack of insight.

${ }^{57}$ Tr. Amos 1.2.7 (CCL 88:270.79-92): Pergit autem propheta crimina diuersa memorare; nam post iniustitiam et superbiam, libidinis peccata contingit: "Filius," inquit, "ac pater eius introierunt ad unam puellam, ut uiolarent nomen sanctum meum" (Amos 2:7c-d). Ostendit in quos cumulos delinquentium consuetudo procedat: primo, inquit, ciuibus iustitiam in iudiciis, affectum in calamitatibus negauistis; secutum est continuo, ut neque naturae ipsius apud uos iura consisterent, sed de flagitiis ad incesta uenientes in scorta filii cum patribus irruebant, ut nullam reuerentiam, sicut prius ciuibus, ita deinceps neque genitoribus exhiberent. Quo sane uestro faciore sanctum quoque meum nomen uiolabatur, colloquentibus inter se uidelicet gentibus: qualis est deus ille, cuius qui peculiaris populus dicitur tam deformis apparet?

${ }^{58} \mathrm{Tr}$. Amos 2.6.1 (CCL 88:299.8).

Josef Lössl, "Pauline Exegesis in Patristic Commentaries of Old Testament Prophets: The Example of Julian of Aeclanum's Tractatus in Amos," in: Journal for Late Antique Religion and Culture 4 (2010) 1-27; ISSN: 1754-517X; Website: http://www.cardiff.ac.uk/clarc/jlarc 
amplifies the force of habit;",59 meaning, he demonstrates in a drastic manner where it can lead, not in order to use it as an excuse to continue with the bad behaviour, but to encourage the audience or the readership to abandon it, and to remind them of their responsibility and their ability to do so.

Julian does not explicitely draw a parallel between Rom 1:18-32 and Amos 2:27. What has so far been presented therefore lacks sufficient hard evidence to state with any certainty Pauline influence upon the passage. But Julian does explicitely refer to the pericope when he discusses Amos 6:1. In this section of his commentary several of the strands already touched upon are converging again. The lemma is well known: "Woe to you who dwell rich and powerful upon Zion, and to you, so self-assured on Mount Samaria etc." ${ }^{60}$ In his exegesis Julian writes:

"God has always had a particular dislike for presumption. So Scripture frequently tells us. It, presumption, is of course the entry point of sin, initium peccati, and it is of such kind that it turns angels into demons. This is also why Saint David expresses his worry that one should fall under the foot of the presumptuous (Ps 35:12). 'For that,' he says, 'is where all those fall who do evil (Ps 35:13).' In making this accusation (increpatio) David keeps to the prophetic order (propheticus ordo). He demonstrates that presumption is more or less the fruit of godlessness. Paul (apostolus) sets out in his sermo (Rom 1:18-32) in the same vein. Those who turn away from God begin to serve creatures, and Paul then lists a series of crimes and misdemeanours and pronounces in addition that those to whom this applies sin excessively (nefandis actibus scatere) on the ground that they violate before God the laws of piety.",61

This passage unites several aspects that were already discussed separately, spread out over a number of passages: 1) Presumption (superbia) is the starting point of sin (initium peccati). Although in itself an allusion to Eccl 10:14, this is early Augustine down to the very terminology, including the fall of the angels. ${ }^{62}$

${ }^{59}$ Turb. frg. 321 (CCL 88:395.443-444): Exaggerat .... apostolus uim consuetudinis.

${ }^{60}$ For an extensive discussion of the verse and its ancient translations see J. Lössl, "Amos 6:1. Notes on Its Text and Ancient Translations," Journal of Northwest Semitic Languages 28 (2002), pp. 43-61.

${ }^{61} \mathrm{Tr}$. Amos 2.6 .1 (299.1-14): “Vae qui opulenti estis in Sion, et confiditis in monte Samariae, optimates capita populorum, ingredientes pompatice domum Israhel” (Amos 6:1). Exosam quidem deo semper fuisse superbiam frequens scriptura commendat, quippe quae initium peccati talis fuerit, ut angelos in daemonas commutaret; unde et beatus Dauid sollicite deprecatur ne subiaceat proculcatui superborum: "Ibi" enim, inquit, “ceciderunt omnes operantes iniquitatem" (Ps 35:12). Hic tamen propheticum ordinem in increpatione custodit, ut superbiam quasi fructum esse impietatis ostendat; per quem tenorem apostoli quoque sermo uidetur ingressus, qui, cum diceret quod creaturis, relicto creatore, seruissent, enumerationem deinceps facinorum flagitiorumque subiecti, propterea illos nefandis actibus scatere pronuntians, quod pietatis erga deum iura temerassent.

${ }^{62}$ Augustine cites the verse more than 150 times in his work, but the emphasis on free will and the fall of the angels in context with it is much stronger in the earlier period, see e. g. Aug. uera

Josef Lössl, "Pauline Exegesis in Patristic Commentaries of Old Testament Prophets: The Example of Julian of Aeclanum's Tractatus in Amos," in: Journal for Late Antique Religion and Culture 4 (2010) 1-27; ISSN: 1754-517X; Website: http://www.cardiff.ac.uk/clarc/jlarc 
2) Saint David, the poet, composer and performer of the Psalms and a prophet in his own right acts here as the prophet as which he was introduced in the overall preface of the Tractatus. He keeps his proclamation to the prophetic order. This is a motif from the preface of the Tractatus. 3) Julian sees the same order also at work in Paul. Rom 1:18-32 sets out the ordo propheticus in the same way as Amos does, or David in Psalms. According to this order the sinner progresses from the basic sin, presumption (superbia), which is ultimately directed against God, to idolatry (worship of creatures), and from there to committing all kinds of other crimes and misdemeanours, in society (injustice), in the family, and even against the elders, as described in the exegesis of Amos 2:4-7.

Paul as Prophet and the Prophet as Evangelist

Thus, as already indicated, Julian's unusually intensive use of Paul in tr. Amos seems motivated by some theological principle or idea, at the core of which might lie Paul's very person. Julian seems to understand Paul as a prophet. This is the topic of the last passage to be discussed in this paper, which is once more to be found at the beginning of the commentary. In his discussion of Amos 1:1 Julian addresses, among others, the question of the prophet's identity and humble background. ${ }^{63} \mathrm{He}$ refers to Amos 7:14-15, where Amos is pointing out the contrast between his origin and his being called to prophecy: "I was neither a prophet nor a prophet's son, but a shepherd and a tender of sycamores, and yet the Lord took hold of me and commissioned me to be a prophet."

"Now this," Julian comments, "is the kind of modest attitude (modestiae uirtus) which Paul, the doctor of nations (doctor gentium), too, displays, when he says, 'To prevent me from becoming presumptuous on the ground of the magnitude of the revelations [that are granted to me] a sting for the flesh was given to me, an angel of Satan who strikes me. Therefore I asked the Lord three times that he leave me. But he [scil. the Lord] told me: 'For you my grace is enough; for virtue is accomplished in weakness (uirtus in infirmitate perficitur).',"

rel. 13.26 (CCL 32:203); lib. arb. 3.76 (CSEL 74:153): initium omnis peccati superbia, citing Eccl 10:14.15, and exp. prop. Rom 4 on Rom 1:21 (CSEL 84:4).

${ }^{63} \mathrm{Tr}$. Amos 1.1.1 (CCL 88:261.34-46): Ergo in Thecue inter pastores loca inculta sed pecori opportuna sectantes, ideo se educatum esse commendat, ne occasione noui muneris uideatur elatus, et de se aliquid aestimare sublatius. Quod propositum seriae parcitatis in processu quoque operis explicauit dicens: "Non eram propheta nec filius prophetae, sed pastor eram ex rubis poma decerpens; et tulit me dominus, et misit ad prophetandum" (Amos 7:14-15). Haec autem modestiae uirtus est, quam et gentium doctor ostendit cum dicit: "Reuelationem magnitudine ne extollerer, datus est mihi stimulus carnis meae, angelus Satanae, qui me colaphizet. Propter quod ter dominum rogaui ut discederet a me, et dixit mihi: Sufficit tibi gratia mea, nam uirtus in infirmitate perficitur" (2 Cor 12:7-9).

Josef Lössl, "Pauline Exegesis in Patristic Commentaries of Old Testament Prophets: The Example of Julian of Aeclanum's Tractatus in Amos," in: Journal for Late Antique Religion and Culture 4 (2010) 1-27; ISSN: 1754-517X; Website: http://www.cardiff.ac.uk/clarc/jlarc 
This comparison of an Old Testament prophet with Paul is unusual. It cannot be found in other commentaries. Jerome's, on which tr. Amos generally depends, and which in turn shows dependencies on Origen's, Eusebius' and Apollinaris', does not go as far as that. In connection with Amos 1:1 it merely cites Amos 7:1415 , without any further explanation, and where Jerome comments on the lemma of Amos 7:14-15 he compares it with the situation of Peter and the other Apostles before the high priest in Jerusalem, where they justify their "prophetic activity" with the words in Acts 5:29: "One must obey God more than men." Jerome thus focuses on the external similarities between the prophet and the Apostles, their being dragged before a religious court and threatened with expulsion, and their standing up against religious authority, similar to Amos. Julian in contrast highlights the prophet's "inner calling" and the paradox it represents, the puzzlement to Amos himself (his humble origin vs. his lofty mission), and he compares this with Paul's call, and its inherent paradox (being a sinner, but at the same time being made perfect by God's grace precisely in his weakness).

What is also interesting in this last passage is the way it picks up phrases first used in the preface of $t r$. Amos:

"Having finished with the explanation of [the book of] saint Joel," the preface begins, "we are now, as far as our ability, with God's help, permits, by the very order of the task before us summonsed to the third prophet, who is called Amos, a man glorified no less by the humility of his kind than by the eminence of his virtue. Lacking entirely the backing of parental privileges, he achieved solely by his own merits (solis meritis) to be numbered among the prophets, who, as I say, are not only guarantors for the magisterium of the Synagogue, but also for the foundation of the church, as the teacher of the nations (magister gentium) testifies, who commends the church to be built on the teaching of the apostles and the prophets." 64

Thus for Julian the message of Amos and Paul is essentially the same. Prophetia is doctrina. ${ }^{65}$ Paul is doctor and magister gentium in the same way as Amos is prophet. God's gratia is man's uirtus, humilitas is modestia, low birth is spiritual aristocracy, achieved by merit alone, solis meritis. This is not mere moralism, as can be found in Jerome, this is some kind of synergism, similar perhaps to that of John Chrysostom. Its purpose within the commentary becomes clear, when we turn to verse 1:2, where the prophet interprets the earthquake, reported in verse 1 , as the voice of God. God's commission has put the prophet into a state of grace in

${ }^{64}$ Tr. Amos praef. (CCL 88:260.1-10): Explanatione sancti Iohelis prout captus noster, adiuuante Deo, pertulit absoluta, ipsa muneris serie uocamur ad tertium prophetam, qui dicitur Amos, uirum non minus generis humilitate quam uirtutis eminentia gloriantem. Nullis quippe parentum fultus insignibus, solis meritis ut in prophetarum numero locaretur obtinuit: prophetarum, inquam, qui non solum magisterium Synagogae, sed etiam fundamentum Ecclesiae praestiterunt, teste magistro gentium, qui aedificari Ecclesiam super doctrinam apostolorum prophetarumque commendat.

${ }^{65}$ Compare above n. 42.

Josef Löss1, "Pauline Exegesis in Patristic Commentaries of Old Testament Prophets: The Example of Julian of Aeclanum's Tractatus in Amos," in: Journal for Late Antique Religion and Culture 4 (2010) 1-27; ISSN: 1754-517X; Website: http://www.cardiff.ac.uk/clarc/jlarc 
which he sees the world with "prophetic eyes" (prophetalibus oculis). ${ }^{66}$ For him the quake is no longer a "natural" (naturae) event, but an expression of God's anger. ${ }^{67}$ Julian contrasts this perspective with ancient scientific theories about the natural causes of earthquakes. Yet it is not these theories in which he is interested, at least not here, ${ }^{68}$ but their relative validity within the framework of a theology which balances nature and grace on the basis of a strong concept of creation, as is also typical for the Julian of the second Pelagian controversy:

"A great many of those who stand out as curious in negotiations of this kind opine that dryness provides the causes of earthquakes, and they try to prove this with examples and to argue for it in disputations. Nevertheless, we need not replicate these [theories] now. I merely mentioned that in passing." ${ }^{, 69}$

For Julian the reason why he should not indulge in a natural explanation of the earthquake here lies in the text: "It will have inflicted a twin calamity, when the commotion has hardly started yet."70

Whatever the natural processes at work, Julian argues, whether a quake caused the drought by upsetting the wells or whether a drought caused the quake by contracting the earth, both remind us of the power of the creator (potentia conditoris), which is also the power of the judge (potentia iudicantis), who in the same way as

${ }^{66}$ Tr. Amos 1.1.1 (CCL 88:261:46-48): Patuit igitur prophetalibus oculis illam terrarum commotionem ad significandam imperii conuulsionem ualere; et hunc esse 'rugitum' domini irascentis appellat: ...

${ }^{67}$ Tr. Amos 1.1.2 (CCL 88:261:49-50): “Et de Hierusalem,” inquit, “dabit uocem suam:” Hanc nimirum uocem quae irae eius congruat, non naturae.

${ }^{68}$ Elsewhere he may have chosen a different line of argument; see J. Lössl, "Teodoro di Mopsuestia e Giuliano di Eclano sulle cause naturali dei terremoti," in: Giuliano d'Eclano e l'Hirpinia christiana. Atti del convegno 4-6 giugno 2003 a cura di Antonio V. Nazzaro (Naples 2004), pp. 103-12; for Julian's attitude to natural science in general see Lössl, Julian von Aeclanum, pp. 78-79.

${ }^{69}$ Tr. Amos 1.1.2 (CCL 88:262.59-63): Plerique enim eorum qui curiosi in eiusmodi negotiis exstiterunt opinantur praebere causas terrarum motibus siccitatem, idque exemplis probare et disputationibus persuadere conantur: quas nunc tamen nobis replicare non est necesse, sed illud breuiter annotaui... Interesting here the negative attitude towards curiositas, which reminds again of Augustine; see A. Labhardt, "Curiositas," Augustinus-Lexikon 2/1-2 (1996), cols. 188-196. But in fact, in the following sentences Julian does again display his typical interest in scientific detail, when he describes the different effects of dryness and humidity on earth movements, even though he does so by relativising the natural explanations in favour of theological explanations; for the type of earthquake theory with which Julian is "playing" here (in antiquity it was attributed to Anaximenes) see P. A. Cartledge, J. R. Sallares, "Earthquakes," The Oxford Classical Dictionary, $3^{\text {rd }}$ ed. (Oxford, 1996), p. 501; for more extensive discussion of the passage see Lössl, Julian von Aeclanum, p. 180 n. 129.

${ }^{70}$ Tr. Amos 1.1.2 (CCL 88:262.63-64): Quia geminam plagam intulerit uixdum inchoata commotio. The "twin plague" consists in the scorching of the pastures and the singeing of Mount Carmel (Amos 1:2; this verse is not cited in the lemma).

\footnotetext{
Josef Lössl, "Pauline Exegesis in Patristic Commentaries of Old Testament Prophets: The Example of Julian of Aeclanum's Tractatus in Amos," in: Journal for Late Antique Religion and Culture 4 (2010) 1-27; ISSN: 1754-517X; Website: http://www.cardiff.ac.uk/clarc/jlarc
} 
he preserves in piety his creation upsets it in his indignation. ${ }^{71}$ However, it is the natural processes through which God works here and as in the polemical works Julian knows no other form of grace than that which has been laid down in and through nature in creation.

\section{Summary and Conclusion}

Julian's use of Paul in tr. Amos is striking. It has implications for the understanding of his use of Paul in his polemical works, particularly Turb. He treats Paul as a prophet, which in the light of early Christian problems with the Pauline concept of prophecy (Montanism!) cannot have been unproblematic in the eyes of his contemporaries. It certainly distinguishes him from Jerome, whose commentary of Amos is otherwise the single most important source for tr. Amos. Not that Julian held an "enthusiastic" concept of prophecy. Yet he does not reject the notion of "ecstasis" either, rather he uses a redefined concept similar to that used by other Pauline commentators at the time. Influence of other Pauline commentators can also be traced in his exegesis of Gal 5:16-18 (Appendix I).

An example of how the Paulinism of $t r$. Amos may influence the understanding of Julian's Pauline exegesis e. g. in Turb. is his understanding of hyperbole. Augustine painted it as a watering down of Paul's arguments, a reduction of Paul's theology to literary-rhetorical criticism. But in the light of Julian's concept of Paul as a prophet and his theology as prophecy it turns out to be a serious theological concept.

At the core of Julian's understanding of Paul lies the person of the apostle himself and his mission, which Julian, with the help of Amos 1:1 and 7:14-15, interprets as a prophetic one. The link between Paul and an Old Testament prophet such as Amos also opened the possibility of understanding Paul's Jewish background and of appreciating the Jewish element in early Christian teaching, as expressed in the statement regarding the two strands of the Prophetic tradition.

Therefore, far from being an obscure commentary of a remote and minor Old Testament prophet, tr. Amos is an important document for understanding Pauline exegesis in the fifth century in general and in the second Pelagian controversy in particular.

Appendix I: Julian and Patristic Exegeses of Gal 5:16-18

In the controversy with Augustine Julian never cites Gal 5:16-18 to support an argument of his own. When he does cite Gal 5.17a-b in Flor. 3.178 (CSEL 85/1,

${ }^{71}$ Tr. Amos 1.1.2 (CCL 88:262.70-71): Qui, ut pietate continet quae creauit, ita eadem, cum opus est, indignatione conturbat.

Josef Lössl, "Pauline Exegesis in Patristic Commentaries of Old Testament Prophets: The Example of Julian of Aeclanum's Tractatus in Amos," in: Journal for Late Antique Religion and Culture 4 (2010) 1-27; ISSN: 1754-517X; Website: http://www.cardiff.ac.uk/clarc/jlarc 
476) it is as part of the Epistula ad Menoch, a document which Julian introduces as a Manichaean document to demonstrate that Augustine's interpretation of the verse is Manichaean, i. e. dualistic and denying free will. In ep. Men. the verse is cited to support the concept of two realities (two souls, duae animae) fighting each other like two persons, one, flesh (caro), "daughter of desire" (filia concupiscentiae), the other, spirit (spiritus), "son of the mind-soul" (filius animae). This duality is suppressing individual free will. The human being is stuck with these two forces and cannot overcome its anti-spiritual desire by its own power. Augustine's discussion of Gal 5.17 in his early, anti-Manichaean, exp. ep. Gal 46 (CSEL 84, 122), too, underlines the importance of the verse in Manichaean exegesis: "People", Augustine writes there, "think that the Apostle is here denying that we have free choice of the will" (putant hic homines liberum uoluntatis arbitrium negare apostolum). There is no evidence that Augustine wrote this specifically with $\mathrm{ep}$. Men. in mind. But that he thought of a current Manichaean exegesis is undeniable. And it was the very first thought that seems to have come to his mind, when he read Gal 5.17.

It is understandable that Julian reacted similarly. His reaction is also interesting in the light of other near contemporary commentaries. Pelagius wrote in his comm. ep. Gal 5.16b: Non quod caro sine anima concupiscat, sed ipsa anima, quando carnalia cogitat, caro dicitur, quando uero spiritalia, unus cum deo fit spiritus. Quamdiu ergo duplex in nobis est desiderium uel uoluntas, non perficimus quaecumque uolumus, uno aedificante in nobis et alio destruente. Clearly one of the main concerns here is to stress the unity of the soul, on the basis of which carnal and spiritual desires struggle against each other. Pelagius' lemma reads desideria carnis. Another variant is concupiscentias, rather than concupiscentiam (desiderium), though variant readings have no decisive influence on the exegesis here. Pelagius' commentary itself might already be influenced by Augustine's anti-Manichaean reading of the passage. Pelagius' note on Gal 5.17a (caro concupiscit aduersus spiritum etc.) reads: carnalis consuetudo aduersus spiritale desiderium. The notion of "habit" (consuetudo) will recur in Julian. The lemma in Jerome's comm. ep. Gal 5.16 reads desiderium carnis. Jerome offers three alternative typological readings, which are yet more moralistic than Pelagius'. In his note on Gal 5.17 he interprets caro and spiritus typologically: caro praesentibus delectatur et breuibus, spiritus perpetuis et futuris. He thinks here of the different soteriological stages which Paul addresses (sub lege and sub gratia, with lex/caro understood here by Jerome as Jewish or pertaining to the Old Covenant, and gratialspiritus as Christian or pertaining to the New Covenant).

Theodore of Mopsuestia has a similar, though more general interpretation. For

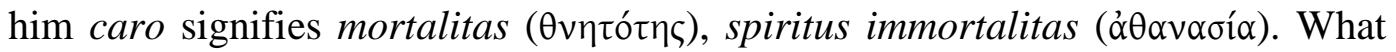
Paul wants to say, he writes, is (ed. Swete I 98): in inmortalitatem ergo uiuere, secundum ut nobis est possibile. illa uero quae sequuntur mortalitatem nolite facere (on this theme in Theodore see U. Wickert, Studien zu den Pauluskommentaren Theodors von Mopsuestia (Berlin, 1962), pp. 101-19). Neither Jerome nor Theo-

Josef Lössl, "Pauline Exegesis in Patristic Commentaries of Old Testament Prophets: The Example of Julian of Aeclanum's Tractatus in Amos," in: Journal for Late Antique Religion and Culture 4 (2010) 1-27; ISSN: 1754-517X; Website: http://www.cardiff.ac.uk/clarc/jlarc 
dore seems to have seen a need to address the problem of dualism here. The "two souls" issue was highlighted by the early Augustine, e. g. in his work De duabus animabus, and implicitely it was also addressed in exp. ep. Gal. Perhaps Pelagius had already taken notice of it when writing his commentary. Ambrosiaster's lemma (CSEL 81/3, p. 59) reads concupiscentiam carnis, but the commentary also interprets concupiscentia morally as (plural!) vitia and the duality of caro and spiritus as duae leges, related to the different soteriological stages (sub lege, sub gratia etc.). Marius Victorinus finally interprets caro even more narrowly than all the other authors as relating to the Jewish law (see S. A. Cooper, Marius Victorinus' Commentary on Galatians (Oxford, 2005), p. 336). This "external" reading is precisely what the late Augustine sought to "overcome". He argued against Julian that Paul wrote to the Galatians as baptised Christians. The struggle between caro and spiritus, therefore, had to be understood as being waged sub gratia, sorting the elect from the non-elect. Julian, influenced mainly by the early Augustine and (negatively) by his own reading of Manichaean sources like the ep. Men., reacts against this. He may or may not have been influenced directly by the tradition represented by the other authors discussed, but generally it is him, not Augustine, who can be situated in this tradition, and he himself certainly was aware of that. For the treatment of the passage in Augustine's exp. ep. Gal see E. Plumer, Augustine's Commentary on Galatians (Oxford, 2003), pp. 208-9; for the line in the Epistula ad Menoch see M. Stein, Manichaica Latina 1. Epistula ad Menoch (Cologne, 1998), pp. 16. 17. 47. And see now also M. Meiser, Galater (Göttingen, 2007), pp. 263-75.

Appendix II: Paul in tr. Amos - Overview (Table)

\begin{tabular}{|c|c|c|c|}
\hline Paul & tr. Amos & CCL 88 & Notes \\
\hline $\begin{array}{l}\text { Rom 1:18- } \\
32\end{array}$ & 2.6.1. & $299.10-14$ & $\begin{array}{l}\text { no citation, but explicit reference to the passage, paraphrase } \\
\text { of parts of it and extensive exegetical treatment analogous } \\
\text { to Amos } 6: 1\end{array}$ \\
\hline Rom 2:4 & $1.5 .18-20$ & 294.344-346 & citation and exegesis \\
\hline Rom 3:19 & $1.1 .3-5$ & $262.85-87$ & citation and exegesis \\
\hline $\begin{array}{l}\text { Rom 3:29- } \\
30\end{array}$ & 2.9 .7 & $324.188-190$ & citation and exegesis \\
\hline 1 Cor $1: 24$ & $1.5 .4-6$ & 287.94 & citation of parts of the verse, no exegesis \\
\hline 1 Cor 3:12 & $1.2 .13-16$ & $272.162-165$ & paraphrase and exegesis \\
\hline 1 Cor 3:12 & 2.9.9-10 & $326.241-242$ & paraphrase and exegesis \\
\hline 1 Cor $14: 3$ & praef. & $260.8-10$ & $\begin{array}{l}\text { allusion, exegesis in key section of the commentary; this } \\
\text { has strong implications }\end{array}$ \\
\hline $\begin{array}{l}1 \text { Cor } \\
15: 28.43\end{array}$ & 2.9.11-12 & $328.331-333$ & $\begin{array}{l}\text { citation of parts of the verse, no exegesis, but significant } \\
\text { because of the use of Paul generally in tr. Amos }\end{array}$ \\
\hline
\end{tabular}




\begin{tabular}{|c|c|c|c|}
\hline 2 Cor $12: 7-9$ & 1.1 .1 & $261.42-46$ & $\begin{array}{l}\text { citation and exegesis; significant because the vocations of } \\
\text { Paul and Amos are explained as analogous }\end{array}$ \\
\hline Gal 1:15-17 & $2.7 .14-16$ & $310.197-200$ & $\begin{array}{l}\text { citation and exegesis; missions of Paul and Amos are } \\
\text { compared and almost treated as equal }\end{array}$ \\
\hline Eph 2:20 & praef. & $260.8-10$ & $\begin{array}{l}\text { paraphrase and exegesis in key section of the commentary; } \\
\text { the messages, or "prophecies", of Amos and Paul and } \\
\text { compared and almost treated as equal }\end{array}$ \\
\hline Phil 3:19 & $1.4 .1-3$ & 278.13 & $\begin{array}{l}\text { citation and exegesis; the transgressions of the addressees } \\
\text { of Amos and Paul are compared as not just moral but } \\
\text { religious (idolatry!) }\end{array}$ \\
\hline $2 \operatorname{Tim} 4: 2.3$ & 1.5 .13 & $\begin{array}{l}292.273-274 \\
\text { and } 284-285\end{array}$ & $\begin{array}{l}\text { citation }(4: 2) \text { and allusion }(4: 3) \text { integrated in an exegesis } \\
\text { which compares Paul's commitment and Amos' treating it } \\
\text { almost as equal }\end{array}$ \\
\hline
\end{tabular}

Appendix III: Paul in Jerome's comm. in Amos - Overview (Table)

\begin{tabular}{|c|c|c|c|}
\hline Paul & $\begin{array}{l}\text { comm. } \\
\text { in Amos }\end{array}$ & CCL 76 & Notes \\
\hline Rom 1:28 & $1.3 .9-10$ & 249.221-222 & $\begin{array}{l}\text { tropology: idolaters are those whom God (metaphorically) } \\
\text { tradat in reprobum sensum; no attempt to relate Paul's } \\
\text { message specifically to Amos' in historical or prophetic } \\
\text { terms as does Iul. Aecl. tr. Amos } 2.6 .1 \text { and Turb. frg. } 165 \text { - } \\
168\end{array}$ \\
\hline Rom 2:4-6 & $1.1 .6-8$ & $221.306-311$ & citation supporting a general point, not specifically Pauline \\
\hline Rom 2:5 & 3.7.1-3 & $315.92-93$ & $\begin{array}{l}\text { allusion combined with citation of Ps } 43: 23 \text {; again not } \\
\text { specifically Pauline; the combination of verses is used to } \\
\text { support a general point }\end{array}$ \\
\hline Rom 2:6 & $2.5 .7-9$ & 281.304-305 & allusion with little exegetical impact \\
\hline Rom 2:12 & $1.2 .4-5$ & $232.115-117$ & $\begin{array}{l}\text { the prophet's sine lege is opposed to Paul's cum lege, } \\
\text { unlike in tr. Amos, where the two are usually equated }\end{array}$ \\
\hline Rom 6:12 & 3.9 .8 & $343.279-280$ & a citation supporting a more general point \\
\hline Rom 7:24 & 2.5.7-9 & $283.374-375$ & a citation supporting a more general point \\
\hline $\begin{array}{l}\text { Rom } \\
8: 9.26\end{array}$ & 2.4.11-13 & $270.501-502$ & $\begin{array}{l}\text { allusions, combined with Ps 103:29 and Lk 23:46; the } \\
\text { specifically Pauline character of the Romans reference is } \\
\text { thereby lost }\end{array}$ \\
\hline $\begin{array}{l}\text { Rom } \\
8: 35.38-39\end{array}$ & $3.7 .7-9$ & $319.235-241$ & $\begin{array}{l}\text { citations combined with Mt } 16: 18 \text {; the Pauline aspect of the } \\
\text { reference is subject to a more general point }\end{array}$ \\
\hline $\begin{array}{l}\text { Rom } \\
11: 21\end{array}$ & 3.8.1-3 & 328.63 & allusion \\
\hline 1 Cor $1: 27$ & 2.6 .1 & $298.23-24$ & citation; no particular emphasis on Paul \\
\hline $\begin{array}{l}1 \text { Cor } \\
3: 12-13\end{array}$ & $1.2 .13-16$ & $241.427-428$ & $\begin{array}{l}\text { typical example: ...hoc est fenum et stipula, de qua et } \\
\text { apostolus dicit and the citation follows; but there is no } \\
\text { evaluating exegesis of the Pauline verse; typical passages } \\
\text { in tr. Amos are very different in that regard }\end{array}$ \\
\hline
\end{tabular}


1 Cor 3:15 3.7.4-6 316.131-132,

$317.149-150$

1 Cor $4: 8$

3.8.11-14

1 Cor $4: 8$

2.5.18-20

335.321-322

292.689-690

$\begin{array}{lll}1 \text { Cor 5:12 } & 1.2 .6-8 & 233.153-156 \\ & & \\ 1 \text { Cor } & 1.2 .6-8 & 234.185-186 \\ 10: 1-2 & & \\ 1 \text { Cor } 10: 4 & 3.6 .12-15 & 310.413 \\ 1 \text { Cor } 11: 3 & 1.2 .9-11 & 239.337 \\ 1 \text { Cor } & 1.2 .9-11 & 239.331-333 \\ 14: 1-5 & & \end{array}$

$\begin{array}{lll}1 \text { Cor } & 2.5 .7-9 & 282.328-330\end{array}$

2 Cor 3:6 1.1.6-8 223.355-356

2 Cor 6:16 2.5.16-17 290.628

2 Cor 9:7 2.5.14-15 288.551

2 Cor 11:2 2.5.3-5 275.114-116

2 Cor $\quad 3.8 .11-14 \quad 334.281-284$

11:2-3

2 Cor

11:14

2 Cor 12:2 3.9.5-6 340.174-175

2 Cor $\quad 2.5 .7-9 \quad 283.359-360$

12:10

2 Cor

13:13

Gal 2:9 3.9.11-12 345.342-343

Gal 2:10 1.2.6-8 234.185-186

Gal 3:22 2.5.18-20 292.685 allusion and citation combined with Is 50:11 and Ez 9:6; the combination with non-Pauline material relativises the Pauline citation citation; not followed up by an exegesis citation combined with 2 Cor 11:29 and allusion to Job 1:5; in the same passage also allusion to 1 Cor 5:1, combined with allusion to Mt 27:5

citation and exegesis reminiscent of tr. Amos 2.6.1 (could there be a link?), but with a different prooftext

citation combined with Deut 32:7, which relativises the Pauline character of the reference

allusion combined with Mt 16:18

faint allusion

faint allusion, no explanation, just paraphrase of Amos in Pauline rhetoric; no historical linkage between Amos and Paul; in all these respects very different from the preface of tr. Amos, which also alludes to the passage citation; in contrast to tr. Amos Jerome opposes Paul and Amos rather than showing them in continuity: Amos is prophecy, Paul is fulfilment

allusion combined with Rom 7:6: spiritus uiuificans citation combined with Mt 28:20

Here the verse is merely cited as a saying: hilarem datorem diligit deus; non-consequential

a citation is combined with Eph 5:27; ecclesiological typology: zelo enim uos zelo dei ... sine macula a citation is combined with allusion to Mt 25.1-15

an allusion combined with $\mathrm{Lk}$ 10:18

an allusion; but here Jerome does make a specifically Pauline point in view of Paul's rapture: ascendit in tertium caelum

citation combined with Lk 16:8; consequently the exegesis follows no specifically Pauline line a citation combined with Ex 34:33-34

an allusion combined with Acts 9:15; typically, no effort at a specifically Pauline exegesis is made here; rather, the basis is widened to bring in other columnae ecclesiae under the concept of uas electionis: Peter, James etc.

citation combined with Prov 13:8; no attempt is made to develop a specifically Pauline exegesis

citation with self-contained explanation: "conclusit omnia sub peccato" ut omnium misereatur 


\begin{tabular}{|c|c|c|c|}
\hline $\begin{array}{l}\text { Gal 4:24- } \\
26\end{array}$ & 1.1.6-8 & $223.361-362$ & an allusion \\
\hline Gal 5:2.4 & $1.2 .6-8$ & $235.217-218$ & $\begin{array}{l}\text { a citation with extensive exegesis: opposition of lex as the } \\
\text { historical context of the prophet and gratia as the historical } \\
\text { context of the apostle; tr. Amos avoids this kind of exegesis } \\
\text { and depicts Amos and Paul in continuity; Jerome in the } \\
\text { same passage also paraphrases Gal 3:27 combining it with } \\
\text { Rom 13:14, and lashes out against heretics of his time } \\
\text { (probably Origenists); the latter, he argues, relate to the } \\
\text { orthodox Christians like the people of the new covenant } \\
\text { (who have gratia) to those of the old (who are slaves of } \\
\text { lex); this heretic bashing is a common feature of Jerome's } \\
\text { commentary and may have led to the view that tr. Amos is a } \\
\text { Rufinian response to it: Lössl, "Julian of Aeclanum's } \\
\text { Tractatus," pp. 11-12 }\end{array}$ \\
\hline Eph 2:14 & 1.3 .8 & $245.83-84$ & citation; no exegesis \\
\hline Eph 6:12 & $3.9 .2-5$ & 339.139 & citation supporting a general point \\
\hline Eph 6:14 & $3.8 .9-10$ & 331.201 & $\begin{array}{l}\text { citation; Jerome's exegesis highlights the contrast of the } \\
\text { situation before and after Christ }\end{array}$ \\
\hline Phil 1:23 & $2.5 .18-20$ & 292.678 & citation combined with Lk 18:11-12 \\
\hline Phil 4:4 & $2.5 .16-17$ & 290.614 & citation, no exegesis \\
\hline $1 \operatorname{Tim} 3: 6$ & $1.2 .6-8$ & 235.201 & $\begin{array}{l}1 \text { Tim 3:6 (citation combined with Is } 14: 13-14 \text {; no } \\
\text { specifically Pauline line of argument developed }\end{array}$ \\
\hline $\begin{array}{l}2 \mathrm{Tim} \\
2 \cdot 19\end{array}$ & 2.5.12-13 & 286.487 & citation; no exegesis \\
\hline
\end{tabular}

Appendix IV: Paul in Cyril's comm. in Amos - Overview (Table)

\begin{tabular}{|c|c|c|c|c|}
\hline Paul & Amos & $\begin{array}{l}\text { Cyril. } \\
\text { comm. } \\
\text { Amos }\end{array}$ & PG 71 & Notes \\
\hline Rom 3:30 & $9: 15$ & 4.85 & 580BD & $\begin{array}{l}\text { citation in combination with Rom } 12: 12 \text { and Eph } 4: 7 \text { in a } \\
\text { summary at the end of the commentary; the focus is on } \\
\text { faith, grace and forgiveness (Pauline themes, but not } \\
\text { integrated into the commentary as a whole) }\end{array}$ \\
\hline Rom 7:23 & $2: 7$ & 1.18 & $444 \mathrm{~A}$ & citation of part of verse; no exegesis; no added significance \\
\hline Rom 9:7 & $9: 7-8$ & 4.82 & $572 \mathrm{D}$ & $\begin{array}{l}\text { Rom 9:7 (filii Abrahae) used to typologically explain Amos } \\
\text { 9:7 (filii Aethiopum); the expression just happens to be } \\
\text { Pauline }\end{array}$ \\
\hline Rom 9:27 & $\begin{array}{l}9: 9- \\
10\end{array}$ & 4.83 & $573 \mathrm{D}$ & $\begin{array}{l}\text { Rom 9:27 combined with Rom } 11: 5 \text { in a summary near the } \\
\text { end of the commentary }\end{array}$ \\
\hline $\begin{array}{l}\text { Rom } \\
11: 11\end{array}$ & $6: 12$ & 3.63 & $528 \mathrm{D}$ & $\begin{array}{l}\text { citation of part of verse; emphasis on the just judge: nec } \\
\text { personas accipit }\end{array}$ \\
\hline
\end{tabular}




\begin{tabular}{|c|c|c|c|c|}
\hline $\begin{array}{l}\text { Rom } \\
11: 25\end{array}$ & $8: 10$ & 4.76 & $556 \mathrm{C}$ & $\begin{array}{l}\text { citation; Paul is named; combination with } 2 \text { Cor } 3: 15 \text {; in so } \\
\text { far Pauline; but there are also many other citations so that } \\
\text { on the whole this part of the commentary does not strike } \\
\text { the reader as Pauline }\end{array}$ \\
\hline Rom 12:3 & $3: 5$ & 2.28 & $458 \mathrm{D}$ & citation of part of verse; no added significance \\
\hline Rom 14:9 & $3: 12$ & 2.32 & $\begin{array}{l}469 \mathrm{D}- \\
472 \mathrm{~A}\end{array}$ & citation stuck to the end of a chapter without any exegesis \\
\hline 1 Cor 5:1 & $2: 7$ & 1.18 & 444B & citation of part of verse; no added significance \\
\hline 1 Cor 7:51 & $6: 6$ & 3.54 & $522 \mathrm{~A}$ & $\begin{array}{l}\text { citation praeterit figura huius mundi; general point: } u t \\
\text { scriptum est, no particular intention on Cyril's part to } \\
\text { highlight the Pauline character of this reference }\end{array}$ \\
\hline $\begin{array}{l}1 \text { Cor } \\
11: 22\end{array}$ & $2: 8$ & 1.19 & 444D & full citation, but no added significance \\
\hline 1 Cor $12: 3$ & $1: 15$ & 1.11 & $436 \mathrm{~A}$ & stuck to the end of the commentary of Amos 1 \\
\hline $\begin{array}{l}1 \text { Cor } \\
13: 1-3\end{array}$ & $8: 4-6$ & 4.73 & $545 \mathrm{D}$ & $\begin{array}{l}\text { allusion; Paul named, but in wider context on the role of } \\
\text { love in salvation }\end{array}$ \\
\hline $\begin{array}{l}1 \text { Cor } \\
15: 33\end{array}$ & $\begin{array}{l}2: 11- \\
12\end{array}$ & 1.22 & $450 \mathrm{D}$ & $\begin{array}{l}\text { citation; but this is merely citing a saying or proverb; not } \\
\text { particularly Pauline and no exegesis is provided }\end{array}$ \\
\hline 2 Cor $2: 15$ & $\begin{array}{l}5: 21- \\
22\end{array}$ & 3.53 & $503 \mathrm{~A}$ & $\begin{array}{l}\text { citation combined with } 1 \text { Cor } 12: 3 \text {; general conclusion of } \\
\text { chapter; no specific exegesis is developed from these } \\
\text { references }\end{array}$ \\
\hline 2 Cor $4: 18$ & $\begin{array}{l}3: 13- \\
15\end{array}$ & 2.33 & 474B & $\begin{array}{l}\text { citation of part of verse at the end of a chapter; here some } \\
\text { Pauline thinking is developed }\end{array}$ \\
\hline 2 Cor 5:17 & $9: 12$ & 4.84 & $577 \mathrm{~B}$ & motif of the new creation \\
\hline 2 Cor 5:20 & $3: 3$ & 2.26 & $458 \mathrm{~A}$ & citation; no added significance \\
\hline 2 Cor $10: 5$ & $6: 2$ & 3.57 & $518 \mathrm{~B}$ & $\begin{array}{l}\text { citation combined with } 2 \text { Cor } 6: 11-14 \text { only to conclude the } \\
\text { commentary on Am } 6: 2 \text {, the exegesis of which was } \\
\text { developed mainly historically along OT references }\end{array}$ \\
\hline Gal 3:24 & $5: 11$ & 2.48 & 497B & $\begin{array}{l}\text { citation combined with Rom } 7: 12 \text {; Paul is presented as } \\
\text { endorsing the law and the law as contributing to salvation } \\
\text { in history; this reminds of the continuity idea in } t r . \text { Amos }\end{array}$ \\
\hline Gal 3:26 & $2: 10$ & 1.21 & 448D & allusion; hint of Pauline thinking, but not sustained \\
\hline Gal 4:9 & $3: 2$ & 2.26 & $457 \mathrm{~A}$ & $\begin{array}{l}\text { Paul is cited as example; this does remind of the use of } \\
\text { Paul in tr. Amos }\end{array}$ \\
\hline Eph 2:6 & $9: 6$ & 4.81 & $570 \mathrm{CD}$ & combined with 1 Thess 4:16; theme: resurrection \\
\hline Eph 4:14 & $2: 4-5$ & 1.14 & 438D & citation illustrating a point; no exegesis \\
\hline Eph 5:5 & $5: 11$ & 2.48 & $500 \mathrm{~B}$ & $\begin{array}{l}\text { citation combined with Rom } 11: 25 \text {; exegesis developing } \\
\text { the thought that even common vices are idolatrous, or } \\
\text { developing from idolatry; combination with Prov } 10: 2 \\
\text { directs attention to aspect of justice; this has similarities } \\
\text { with } t r . \text { Amos ad loc. }\end{array}$ \\
\hline Eph 5:9 & $9: 8$ & 4.82 & $573 \mathrm{~A}$ & citation of part of verse; no added significance \\
\hline Eph 6:12 & $2: 9$ & 1.20 & $448 \mathrm{C}$ & full citation; Pauline thought is developed to some extent \\
\hline Phil 3:1 & $\begin{array}{l}3: 13- \\
15\end{array}$ & 2.33 & $472 \mathrm{~B}$ & Paul cited as example \\
\hline
\end{tabular}




\begin{tabular}{|c|c|c|c|c|}
\hline Phil 3:10 & $9: 5$ & 4.80 & $568 \mathrm{BC}$ & $\begin{array}{l}\text { citation and allusion; thought developed, but in } \\
\text { combination with other biblical quotations }\end{array}$ \\
\hline Phil 3:21 & $9: 6$ & 4.81 & $571 \mathrm{AB}$ & $\begin{array}{l}\text { combined with } 2 \text { Cor } 3: 6 \text { (littera occidit, spiritus reuiuicat) } \\
\text { in summary towards the end of the commentary }\end{array}$ \\
\hline $1 \operatorname{Tim} 2: 4$ & $3: 6$ & 2.29 & $461 \mathrm{~A}$ & $\begin{array}{l}\text { citation; God's punishments will in the long term turn out } \\
\text { to be beneficial }\end{array}$ \\
\hline $\begin{array}{l}1 \mathrm{Tim} \\
6: 15\end{array}$ & $4: 13$ & 2.42 & $488 \mathrm{D}$ & $\begin{array}{l}\text { Pauline verse cited in cluster with other verses to develop a } \\
\text { more general line of thought }\end{array}$ \\
\hline
\end{tabular}

Appendix V: The Presence of Rom 1:18-32 in Turb. and tr. Amos

\begin{tabular}{|c|c|c|c|c|c|}
\hline Rom & $\begin{array}{l}\text { Turb. } \\
\text { frg. }\end{array}$ & tr. Amos & Text in Rom & Text in Julian & Notes \\
\hline $1: 21 \mathrm{c}$ & 172 & - & $\begin{array}{l}\text { obscuratum [contenebratum] } \\
\text { est insipiens cor eorum }\end{array}$ & $\begin{array}{l}\text { tenebris oppletum est } \\
\text { insipiens cor eorum }\end{array}$ & $\begin{array}{l}\text { Cf. CiC. or. post } \\
\text { red. in Sen. } 10\end{array}$ \\
\hline $1: 23$ & 165 & - & \multicolumn{2}{|c|}{$\begin{array}{l}\text { immutauerunt gloriam incorruptibilis dei in similitudinem } \\
\text { imaginis corruptibilis hominis et uolucrum et quadrupedum } \\
\text { et serpentium... }\end{array}$} & citation in frg. 165 \\
\hline $\begin{array}{l}1: 24- \\
25\end{array}$ & $\begin{array}{l}165 \\
(1: 24)\end{array}$ & $\begin{array}{l}2.6 .1 \\
(1: 24- \\
25)\end{array}$ & $\begin{array}{l}\text { tradidit illos deus in } \\
\text { desideria cordis eorum in } \\
\text { immunditiam, ut afficiant } \\
\text { corpora sua in semetipsis, } \\
\text { qui commutauerint } \\
\text { ueritatem dei in } \\
\text { mendacium, et coluerunt et } \\
\text { seruierunt creaturae potius } \\
\text { quam creatori, qui est } \\
\text { benedictus in saecula, } \\
\text { amen. }\end{array}$ & $\begin{array}{l}\text { tr. Amos } 2.6 .1 \text { (CCL } \\
\text { 88:299.10-14): per quem } \\
\text { tenorem apostoli quoque } \\
\text { sermo uidetur ingressus, } \\
\text { qui, cum diceret quod } \\
\text { creaturis, relicto creatore, } \\
\text { seruissent, enumerationem } \\
\text { deinceps facinorum } \\
\text { flagitiorumque subiecit, } \\
\text { propterea illos nefandis } \\
\text { actibus scatere pronuntians, } \\
\text { quod pietatis erga deum } \\
\text { iura temerassent. }\end{array}$ & $\begin{array}{l}\text { 1:23-24 cited in } \\
\text { Turb. frg. 165, 1:24- } \\
25 \text { alluded to in } t r . \\
\text { Amos; with similar } \\
\text { exegesis in both } \\
\text { works; the idolatry } \\
\text { theme is also } \\
\text { developed in } t r . \\
\text { Osee 2.7.1 }\end{array}$ \\
\hline
\end{tabular}

$1: 26 \quad-\quad-\quad \begin{aligned} & \text { propterea tradidit illos deus in } \\ & \text { passiones ignominiae }\end{aligned}$

$1: 27 \quad-\quad \quad-\quad$ similiter autem et masculi relicto naturali usu feminae exarserunt in desideriis suis in inuicem masculi in masculos no citation in either work, but motif of traditio in verses 24 and 28 is carried through and applied to concrete vices (passiones) in both Turb. 165-168 and tr. Amos 1.2.4-7 and 2.6.1

Turb. frg. 166: Iam not cited, but enim flagitiorum allusion in frg. 166 desideriis aestuabant. (desideriis

aestuabant) 


\begin{tabular}{|c|c|c|c|c|c|}
\hline & & & \multicolumn{3}{|l|}{$\begin{array}{l}\text { turpitudinem operantes et } \\
\text { mercedem quam oportuit } \\
\text { erroris sui in semetipsis } \\
\text { recipientes. }\end{array}$} \\
\hline $1: 28$ & 165 & - & \multicolumn{2}{|c|}{$\begin{array}{l}\text { tradidit illos deus in reprobum sensum, ut faciant quae non } \\
\text { conueniunt }\end{array}$} & cited \\
\hline $\begin{array}{l}1: 29- \\
30\end{array}$ & - & - & $\begin{array}{l}\text { repletos omni iniquitate, malitia } \\
\text { fornicatione auaritia nequitia } \\
\text { plenos inuidia homicidio, } \\
\text { contentione dolo malignitate } \\
\text { susurrones detractatores deo } \\
\text { odibiles contumeliosos } \\
\text { superbos elatos inuentores } \\
\text { malorum parentibus non } \\
\text { oboedientes }\end{array}$ & & $\begin{array}{l}\text { not cited, but the } \\
\text { theme is alluded to } \\
\text { in Turb. frg. 166- } \\
168 \text { and tr. Amos } \\
1.2 .6-7 \text { (CCL } \\
88: 269.70-270.92 \text { ) }\end{array}$ \\
\hline $\begin{array}{l}1: 31- \\
32\end{array}$ & - & - & $\begin{array}{l}\text {...qui cum iustitiam dei } \\
\text { cognouissent non intellexerunt } \\
\text { quoniam qui talia agunt digni } \\
\text { sunt morte }\end{array}$ & $\begin{array}{l}\text { tr. Amos 1.2.6 (CCL } \\
\text { 88:270.77-79): non } \\
\text { solum neglegere, sed } \\
\text { etiam odisse iustitam } \\
\text { deteguntur }\end{array}$ & $\begin{array}{l}\text { possible allusion in } \\
\text { tr. Amos } 1.2 .6\end{array}$ \\
\hline
\end{tabular}

